\title{
PRODUKSI DAN KARAKTERISASI ANTIBODI MONOKLONAL (MAB) ANTI-Mycobacterium fortuitum UNTUK DIAGNOSIS PENYAKIT MIKOBAKTERIOSIS PADA IKAN
}

\author{
Hambali Supriyadi"), Taukhid"), dan Adin Priadi")
}

\begin{abstract}
ABSTRAK
Keberhasilan penanggulangan penyakit ikan ditentukan oleh hasil diagnosis penyakit tersebut. Cara diagnosis yang cepat dan tepat akan menghasilkan cara penanggulangan yang cepat dan tepat pula. Tujuan dari penelitian ini adalah untuk menghasilkan alat diagnosis yang cepat dan tepat untuk penyakit mikobakteriosis. Antigen yang berasal dari bakteri Mycobacterium fortuitum dicampur dengan "Incomplete Freuds Adjuvanf' disuntikkan ke tubuh mencit Balb/c dengan dosis $0,1 \mathrm{~mL} /$ ekor $\left(10^{9} \mathrm{cfu} / \mathrm{ekor}\right)$. Penyuntikan ulang (booster) dilakukan pada minggu kedua dan ketiga. Setelah antibodi dalam tubuh mencit mencukupi $\left(\log _{10} 2-3\right)$, dilakukan penyuntikan akhir sebanyak 0,2 mLekor. Fusi dilakukan antara sel limfosit dengan mieloma Sp2/0-Ag, dan setelah terbentuk hibrid kemudian dilakukan proses kloning. Produksi antibodi monoklonal dilakukan dalam Magnaflex-Flasks. Karakterisasi dan isotiping dilakukan terhadap produk tersebut. Data hasil antibodi monoklonal yang disekresikan oleh hibridoma pada cawan I menunjukkan bahwa hibridoma yang ada pada lubang No. A3, B1, B2, C2, D3, D7, dan $\mathrm{H} 2$ serta No. A8, B4, D3, D7, E1, F9, dan G4 pada cawan 2 merupakan hibridoma yang banyak mengeluarkan sekresi antibodi monoklonal. Dari hasil isotiping ini ternyata antibodi monoklonal yang diperoleh terdiri atas $\operatorname{lgG} 1$ dan $\lg$ 2.
\end{abstract}

\section{ABSTRACT: Production and characterization of monoclonal antibody anti-Mycobactrium fortuitum used for diagnostic tool for mycobacteriosis. By: Hambali Supriyadi, Taukhid, and Adin Priadi}

\begin{abstract}
The success of control of fish disease depends on the accuracy of diagnostic result. Rapid and accurate method of diagnostic used will lead to the accurate and rapid control of fish disease. This research aimed to establish the accurate and rapid diagnostic tool for mycobacteriosis. Antigen made from Mycobacterium fortuitum was mixed with Incomplete Freuds Adjuvant, and then injected into Balb/C mice at the dose of $0.1 \mathrm{~mL}$ or equivalent with $10^{\circ} \mathrm{cfu} /$ mice. Boosters with the same dose were given at Week 2 and Week 3 . After high titer antibody in the blood attained (log $_{10}$ 2-3), the mice were then boostered with $0.2 \mathrm{~mL}$ mice. Fusion between lymphocyte and myeloma SP2/O-Ag was done and then cultured in DMEM medium supplemented with 10\% Foetal Calf Serum (FCS) and Hypoxanthine-Aminopterin-Thymidine (HAT). The hybrids were cultured in DMEM enriched wit 5\% FCS and Hypoxanthine-Thymidine (HT) and then clonned. Productions of monoclonal antibody (MAb) was conducted in "Magnaflex" Flask. Characterization and iso-typing were done by comparing with commercially available immunoglobulin. The result indicated that some hybrids at cell nos. $A 3, B 1, B 2, C 2, D 3, D 7, H 2$ in plate 1 and cell nos. $A 8, B 4, D 3, D 7, E 1, F 9$, and $G 4$ in plate 2 produced MAb. Result from the isotyping test indicated that the MAb contained immunoglobulin IgG1 and AgG2.
\end{abstract}

\section{KEYWORDS: mycobacteriosis, monoclonal antibody, Mycobacterium fortuitum}

\section{PENDAHULUAN}

Penyakit bercak merah pada ikan air tawar yang disebabkan oleh bakteri Aeromonas hydrophila merupakan masalah serius pada usaha budi daya (Supriyadi \& Taufik, 1981; Taufik, 1992) karena dapat mengakibatkan kematian ikan antara 50\%-100\% (Supriyadi \& Rukyani, 1990). Keterlambatan penanggulangan penyakit tersebut yang disebabkan oleh penggunaan teknik diagnosis konvensional melalui serial uji biokimia merupakan masalah umum yang sering dihadapi. Kesalahan diagnosis akibat penggunaan metode diagnosa juga sering terjadi, sehingga tindak penanggulangan yang diberikan juga tidak tepat dan akhirnya mengakibatkan kerugian yang lebih besar.

Teknik diagnosis cepat dengan menggunakan antibodi monoklonal terhadap mikroorganisme yang

, Peneliti pada Balai Penelitian Perikanan Air Tawar, Sukamandi

- Mahasiswa Institut Pertanian Bogor 
lambat tumbuh seperti mikobakterium atau yang sulit dikultur seperti virus, merupakan terobosan besar dalam proses identifikasi mikroorganisme penyebab penyakit baik pada manusia maupun hewan (Adams et al.,1996; Chu et al., 1997). Diagnosis penyakit bakterial pada ikan dengan metode serologis umumnya dapat dilakukan dengan cepat, namun sering terjadi kesalahan diagnosis karena menggunakan antibodi yang kurang spesifik. Penggunaan antibodi monoklonal untuk tujuan tersebut dapat mengurangi tingkat kesalahan yang terjadi (Campbell, 1986).

Pengembangan "antibody probes (polyclonaldan monoclonal" pada penyakit ikan akan sangat berguna, baik sebagai alat untuk mendiagnosis secara cepat (immunodiagnosis) maupun tindak penanggulangannya (Adams et al., 1995). Penggunaan antibodi monoklonal dalam bidang imunologi perikanan pada hakekatnya sudah banyak dikerjakan, seperti untuk studi imunoglobulin (lg) serum pada ikan channel catfish (Lobb \& Clem, 1982); pada ikan trout (DeLuca et al., 1983); dan pada kelompok ikan Cyprinus carpio (Secombes et al., 1983). Beberapa jenis antibodi monoklonal juga telah dapat digunakan untuk studi fungsional terhadap permukaan reseptor pada non specific cytotoxic cells dan sel -B (Lobb \& Clem, 1982).

Penggunaan antibodi monoklonal untuk keperluan diagnosis penyakit ikan dan udang telah dilaporkan oleh Kaatari et al. (1986) dan Adams et al. (1995), antara lain terhadap penyakit Renibacterium salmoninarum dan Mycobacterium sp. MAb tersebut merupakan antibody probes yang sangat spesifik, sehingga dapat digunakan sebagai perangkat imunologi yang ampuh dalam teknik diagnosis seperti ELISA, imunohistokhemistri dan imunofluo-rescence (Harlow \& Lane, 1988 dalam Adams, 1995).

Penyakit bakterial yang disebabkan oleh bakteri Mycobacterium sp. terutama pada ikan konsumsi dan ikan hias telah banyak dilaporkan (Nigrelli \& Vogel, 1963; Chinabut et al., 1990). Penyakit tersebut dapat menimbulkan kematian lebih dari $20 \%$ pada ikan gabus (Limsuwan et al., 1983) dan menurunkan mutu ikan itu sendiri.

Gejala klinis infeksi bakteri tersebut seperti mata menonjol (exopthalmos), adanya benjolan pada tubuh, dan terdapatnya bintil-bintil putih (tubercle) pada ginjal, hati, dan limpa telah terlihat pada ikan gurami.

Monokional antibodi (Mab) yang disekresikan oleh sel hibridoma merupakan antibody probes yang spesifik, homogen, dan ampuh sebagai alat diagnosis (immunodiagnostic tools) penyakit ikan (Campbell, 1986; Kaatari et al., 1986; Harlow \& Lane, 1988). Antibodi monoklonal anti Aeromonas hydrophila strain
26 sudah dapat diproduksi (Supriyadi et al., 1997); dan telah digunakan untuk mendiagnosis penyakit infeksi bakteri $A$. hydrophila pada ikan air tawar (Supriyadi et al., 1997). Tujuan penelitian ini untuk mendapatkan antibodi monoklonal anti Mycobacterium $\mathrm{sp}$. yang diharapkan dapat digunakan sebagai alat untuk mendiagnosis penyakit tuberkulosis pada ikan secara cepat, dan sebagai bahan untuk imunisasi pasif.

\section{BAHAN DAN METODE}

\section{Antigen dan Imunisasi}

Antigen yang digunakan pada percobaan ini adalah bakteri Mycobacterium fortuitum yang diisolasi dari ikan gurami sakit, hasil penelitian 1998/1999. Isolat murni dibiakkan dalam media Shautons selama 7 hari dan dilakukan pemanenan sistem kering. Suspensi antigen dicuci dua kali dengan larutan garam fisiologis (salin 0,85\%); dan diinaktivasi dengan alkohol $(3 \% \mathrm{v} / \mathrm{v})$ selama 15 menit. Kadar protein sediaan antigen dioptimasi menggunakan metode Lawry et al. (1951) dan dianalisis dengan metode Enzyme Linked Immunosorbent Assay (ELISA).

Mencit Balb/c berumur 8 minggu diinjeksi antigen (priming) yang dicampur dengan Incomplete Freund's Adjuvant (IFA) dengan perbandingan 1:1 (v/v) dan dilakukan secara intraperitoneal pada dosis $0,1 \mathrm{~mL} /$ ekor atau setara dengan $10^{9} \mathrm{cfu} / \mathrm{ekor}$ mencit. Pada minggu ke-2 dan ke-3 dilakukan injeksi ulang (booster) dengan antingen dan dosis yang sama seperti pada saat penyuntikan yang pertama. Setelah diketahui bahwa kadar antibodi yang terbentuk cukup tinggi $\left(\log _{10}\right.$ 2-3) berdasarkan hasil pengukuran dengan teknik ELISA, maka dilakukan injeksi terakhir dengan antigen serupa tanpa penambahan IFA dan diberikan secara intra vena pada dosis 0,2 mL/ekor. Empat hari kemudian dari saat penyuntikan terakhir, dilakukan pemfusian sel limfosit hiperimun dengan sel mieloma $\mathrm{Sp}-2 / \mathrm{O}-\mathrm{Ag}$.

\section{Hibridasi, Kloning, dan Skrining Antibodi}

Suspensi sel limpa mencit dicuci dua kali dengan Dubelco Modified Eagle's Medium (DMEM), Ialu diproses hingga diperoleh suspensi splenosit yang siap difusikan dengan sel lestari (mieloma) Sp2/0-Ag. Penghitungan konsentrasi sel limfosit dan sel lestari dilakukan menurut metode Schots et al. (1992) masing-masing dengan menggunakan larutan turk dan tryphan blue.

Fusi antara sel limfosit dengan sel lestari dilakukan menurut Thorns \& Morris (1983) dengan bantuan larutan PEG 4000 (Kohler \& Milstein, 1975) selama 60 detik. Sel hasil fusi dibiakkan dalam DMEM yang 
disuplementasi dengan $10 \%$ foetal calf serum (FCS) dan Hypoxanthine-Aminopterin-Thymidine (HAT). Setelah terbentuk hibrid, media yang digunakan adalah DMEM yang diperkaya dengan $5 \%$ FCS dan Hypoxanthine-Thymidine (HT).

Kloning sel hibridoma dilakukan mengikuti prosedur pada metode pelarutan terbatas (Thorns \& Morris, 1983); ditumbuhkan dalam DMEM yang disuplementasi dengan Peritoneum Exudate Cells (PEC). Pertumbuhan sel-sel hibrid yang telah dikloning dimonitor tiap hari, dan terhadap sel hibridoma yang normal segera dilakukan skrining terhadap hasil sekresinya dengan teknik ELISA.

\section{Produksi Antibodi Monoklonal}

Produksi antibodi monoklonal dilakukan secara in vitro. Produksi secara in vitro dilakukan dalam imunoglobulin spesifik komersial dengan teknik ELISA (Schots et al., 1992). Imunoglobulin spesifik yang digunakan adalah IgG-1, IgG-2, IgG-2b, IgG-3, IgA, dan IgM.

\section{HASIL DAN BAHASAN}

Hasil dari titrasi antigen yang dilakukan dengan pengenceran antigen 1:400 menunjukkan pengenceran yang maksimal, sehingga reaksi antara antigen dan antibodi dapat terjadi, dan pada tahap pengenceran tersebut hasil reaksi terjadi cukup bagus. Sedangkan pada pengenceran yang lebih rendah walaupun hasilnya cukup bagus tapi boros dalam penggunaan antigen (Tabel 1).

Tidak semua hibridoma yang dihasilkan dapat mensekresikan antibodi monoklonal dengan jumlah

Tabel 1. Nilai titrasi antigen Mycobacterium fortuitum dengan konjugat pada pengenceran $1 / 2.000$, dan serum pada 1/100, serta antigen pada pengenceran 1/50 s/d 1/1.600 dalam uji Enzyme Linked Immunosorbent Assay (ELISA) pada $414 \mathrm{~nm}$

Table 1. The titer of Mycobacterium fortuitum with conjugate dilution of 1/2.000, serum of 1/100, and antigen dilution of $1 / 50$ to $1 / 1.600$ in ELISA test at $414 \mathrm{~nm}$

\begin{tabular}{ccc}
\hline $\begin{array}{c}\text { Pengenceran Antigen } \\
\text { Antigen Dilution }\end{array}$ & OD (positive) & OD (negative) \\
\hline $1: 50$ & 1.503 & 0.162 \\
& 1.472 & 0.138 \\
$1: 100$ & 1.264 & 0.131 \\
& 1.399 & 0.137 \\
$1: 200$ & 1.181 & 0.133 \\
& 1.213 & 0.152 \\
$1: 400$ & 0.737 & 0.146 \\
& 0.713 & 0.131 \\
$1: 800$ & 0.467 & 0.143 \\
& 0.437 & 0.142 \\
$1: 1600$ & 0.237 & 0.138 \\
& 0.323 & 0.137 \\
\hline
\end{tabular}

Keterangan: $O D=$ nilai densitas optik

Note: $\quad O D=$ value of optical density

Magnaflex-Flasks menurut metode yang dikembangkan oleh Campbell (1986) terhadap klon hibrid yang potensial. Media yang digunakan adalah DMEM dengan $2 \%$ FCS.

\section{Karakterisasi dan Isotiping Antibodi Monoklonal}

Uji kepastian sifat monoklonal dari antibodi monoklonal yang dihasilkan dilakukan dengan teknik immunoblotting. Sedangkan determinasi MAb hasil produksi dilakukan dengan menggunakan yang banyak, hal ini dapat dilihat dari uji ELISA yang dilakukan terhadap sekresi dari beberapa hibridoma.

Dari data hasil antibodi monoklonal yang disekresikan oleh hibridoma pada cawan । menunjukkan bahwa hibridoma No. A3, B1, B2, C2, D3, D7, dan $\mathrm{H} 2$ merupakan hibridoma yang banyak mengeluarkan sekresi antibodi monoklonal. Titer antibodi monoklonal yang dihasilkan cukup tinggi terbukti dengan masih dapat bereaksi pada pengenceran serum sebanyak 1:400. Dari data tersebut di atas densitas optik dari lubang yang 
menghasilkan antibodi monoklonal pada A3, D3, dan $\mathrm{H} 2$ ternyata nilainya sama dengan kontrol positif pada G8 dan G9. Hal yang sama terjadi pada cawan 2 di mana pada B4 nilainya mendekati kontrol positif pada G8 dan G9 (Tabel 2). digunakan dalam memproduksi monoklonal antibodi. Adapun kegunaan dari monoklonal antibodi tersebut selain dapat dimanfaatkan untuk alat diagnosis yang tepat juga dapat digunakan untuk membentuk kekebalan. Dari nilai absorbansi dapat diketahui bahwa

Tabel2. Nilai absorban dari supernatan yang disekresikan oleh hibridoma anti Mycobacterium fortuitum pada cawan I

Table 2. The absorbance value of supernatant secreted by hybridoma anti-Mycobacterium fortuitum in plate I

\begin{tabular}{ccccccccccc}
\hline $\begin{array}{c}\text { Seri lubang } \\
\text { Hole series }\end{array}$ & \multicolumn{6}{c}{$\begin{array}{c}\text { Nilai absorban supernatan yang dise kresikan oleh hibridoma pada cawan I } \\
\text { The absorbance value of supernatant secreted by hybridoma in plate I }\end{array}$} \\
\cline { 2 - 11 } & $\mathbf{1}$ & $\mathbf{2}$ & $\mathbf{3}$ & $\mathbf{4}$ & $\mathbf{5}$ & $\mathbf{6}$ & $\mathbf{7}$ & $\mathbf{8}$ & $\mathbf{9}$ \\
\hline A & 0.282 & 0.318 & $\mathbf{1 . 3 4 2}$ & $\mathbf{0 . 1 8 6}$ & 0.298 & 0.304 & 0.296 & 0.287 & 0.342 \\
B & $\mathbf{1 . 2 7 1}$ & 0.196 & 0.273 & 0.293 & 0.273 & 0.291 & 0.273 & 0.287 & 0.281 \\
C & 0.307 & $\mathbf{1 . 2 3 6}$ & 0.261 & 0.29 & 0.274 & 0.296 & 0.248 & 0.281 & 0.272 \\
D & 0.355 & 0.295 & 1.381 & 0.292 & 0.289 & 0.274 & 1.288 & 0.355 & 0.279 \\
E & 0.268 & 0.347 & 0.294 & 0.287 & 0.303 & 0.273 & 0.309 & 0.303 & 0.295 \\
F & 0.323 & 0.319 & 0.237 & 0.295 & 0.293 & 0.252 & 0.290 & 0.284 & 0.299 \\
G & 0.310 & 0.295 & 0.311 & 0.285 & 0.278 & 0.266 & 0.291 & 1.420 & 1.383 \\
H & 0.381 & $\mathbf{1 . 3 5 7}$ & 0.250 & 0.274 & 0.310 & 0.300 & 0.280 & 0.242 & 0.254 \\
\hline
\end{tabular}

Keterangan: sel yang dicetak tebal adalah supernatan yang memperlihatkan nilai absorban yang cukup tinggi dibanding dengan lainnya. Sedangkan sel No. G8 dan G9 merupakan nilai kontrol positif dan sel No. $\mathrm{H} 8$ dan $\mathrm{H} 9$ merupakan nilai kontrol negatif

Note: Cell printed in bold indicated high absorbance value that secreted by hybridoma. Cell nos. G8 and G9 the value of positive control meanwhile cell nos. $\mathrm{H} 8$ and $\mathrm{H} 9$ the value of negative control

Agar antibodi monoklonal yang dihasilkan dapat dipakai untuk diagnosis, harus memiliki sifat yang sangat spesifik terhadap antigen asalnya. Kespesifikan ini tidak lagi dalam tahap spesies melainkan sampai tahap strain atau sub-spesies. Oleh karena itu terhadap sekresi yang berasal dari lubang yang menunjukkan produksi antibodi monoklonal tersebut kemudian diuji immunoglobulin spesifiknya melalui uji isotiping. Sebagai pembanding digunakan immunoglobulin yang secara komersial mudah didapat yaitu IgG-1, IgG-2, IgG-2b, IgG-3, IgA, dan IgM. Dari hasil isotiping ini ternyata antibodi monoklonal yang diperoleh terdiri atas $\lg$ G1 dan IgG2. Hasil ini sesuai dengan yang telah didapatkan Adams et al. (1996) yang hanya mendapatkan IgG1 dan IgG2 dari 6 monoklonal antibodi yang diproduksi dari Mycobacterium sp.

Demikian juga hasil dari uji reaksi antigen antibodi yang diuji melalui uji ELISA pada cawan 2 (Tabel 3) menunjukkan bahwa hibrid pada lubang No. A8, B4, D3, D7, E1, F9, dan G4 merupakan hibrid yang banyak menyekresikan monoklonal antibodi yang paling banyak. Hal ini berarti bahwa hibridoma-hibridoma tersebut dapat dipilih dan dikoleksi untuk dapat hibridoma $\mathrm{A} 3, \mathrm{D} 3$, dan $\mathrm{H} 2$ yang terdapat pada cawan 1 serta B4 pada cawan No. 2 merupakan hibrid yang paling banyak menyekresikan antibodi monoklonal. Sehingga dapat dipertimbangkan bahwa hibridomahibridoma tersebut merupakan bahan yang tepat untuk dipakai dalam produksi monoklonal antibodi. Namun demikian perlu diuji terlebih dahulu spesifitas antibodinya berdasarkan pada jenis immunoglobulin yang dihasilkannya.Dari hasil uji tersebut ternyata menunjukkan bahwa immunoglobulin IgG1 dan IgG2 merupakan komponen immunoglobulin dari sekresi yang dihasilkan.

Dari data hasil isotiping yang menunjukkan hasil yang sama baik yang diperoleh dari cawan I maupun cawan 2 menunjukkan adanya kesamaan dari hibridoma yang ada pada cawan 1 maupun cawan 2 . Kesamaan tersebut melambangkan spesivitas dari antibodi monoklonal yang dihasilkan oleh masingmasing hibridoma.

Untuk produksi massal dari antibodi monoklonal ini pada prinsipnya dapat dilakukan dengan menggunakan tissue culture (T/C) maupun dengan menyuntikkan hibridoma tersebut ke dalam tubuh mencit. Namun dari 
Tabel 3. Nilai absorbance dari supernatan yang disekresikan oleh hibridoma anti Mycobacterium fortuitum pada cawan II

Table 3. The absorbance of supernanat secreted by hybridoma anti-Mycobacterium fortuitum in plate II

\begin{tabular}{|c|c|c|c|c|c|c|c|c|c|}
\hline \multirow[t]{2}{*}{$\begin{array}{l}\text { Seri lubang } \\
\text { Hole series }\end{array}$} & \multicolumn{9}{|c|}{$\begin{array}{l}\text { Nilai absorban dari supernatan yang disekresikan oleh hibridoma pada cawan II } \\
\text { The absorbance value of supernatant secreted by hybridoma in plate II }\end{array}$} \\
\hline & 1 & 2 & 3 & 4 & 5 & 6 & 7 & 8 & 9 \\
\hline A & 0.232 & 0.249 & 0.183 & 0.229 & 0.236 & 0.225 & 0.242 & 0.916 & 0.222 \\
\hline$B$ & 0.208 & 0.201 & 0.207 & 1.317 & 0.213 & 0.184 & 0.185 & 0.207 & 0.217 \\
\hline$C$ & 0.215 & 0.203 & 0.182 & 0.174 & 0.212 & 0.187 & 0.214 & 0.203 & 0.226 \\
\hline$D$ & 0.219 & 0.197 & 1.287 & 0.175 & 0.175 & 0.173 & 1.106 & 0.19 & 0.195 \\
\hline$E$ & 1.072 & 0.218 & 0.176 & 0.173 & 0.227 & 0.206 & 0.206 & 0.191 & 0.193 \\
\hline $\mathrm{F}$ & 0.193 & 0.208 & 0.177 & 0.18 & 0.178 & 0.178 & 0.199 & 0.245 & 1.238 \\
\hline $\mathrm{G}$ & 0.224 & 0.204 & 0.187 & 1.244 & 0.193 & 0.194 & 0.086 & 1.444 & 1.420 \\
\hline $\mathrm{H}$ & 0.338 & 0.192 & 0.213 & 0.214 & 0.211 & 0.212 & 0.994 & 0.177 & 0.206 \\
\hline
\end{tabular}

Keterangan: sel yang dicetak tebal adalah supernatan yang memperlihatkan nilai absorban yang cukup tinggi dibandingkan dengan yang lainnya. Sedangkan sel No. G8 dan G9 merupakan kontrol positif dan sel $\mathrm{H} 8$ dan $\mathrm{H} 9$ merupakan nilai kontrol negatif

Note:

Cell printed in bold indicated high absorbance value that secreted by hybridoma. Cell No. G8 and G9 the value of positive control mean while cell No. H8 and H9 the value of negative control

segi kemurniannya lebih disarankan untuk menggunakan T/C.

\section{KESIMPULAN}

Antibodi monoklonal ternyata dapat disekresikan oleh hibridoma hasil fusi dari sel limfosit dengan sel myeloma Sp2/O-Ag. Banyaknya antibodi monoklonal yang disekresikan akan tergantung pada klon hibridoma itu sendiri.

Untuk memperoleh antibodi monoklonal yang lebih murni maka produksinya lebih disarankan untuk mengggunakan metode tissue culture (TC).

\section{DAFTAR PUSTAKA}

Adams, A., K.D. Thompson, H. McEwan, S. Chen, and R.H. Richard. 1995. Development of monocional antibodies to Mycobacteria sp. isolated from snake head (Chana striatus) and Siamese fighting fish (Betta splendens). J. Aquatic Animal Health. (in press).

Adams, A., K.D. Thompson, H. McEwan, S. Chen, and R.H. Richard. 1996. Development of monoclonal antibodies to Mycobacteria sp. isolated from snake head (Chana striatus) and Siamese fighting fish (Betta splendens). J. Aquatic Animal Health. 8, 208215.

Campbell, A.M. 1986. Monoclonal Antibody Technology. Laboratory Techniques in Biochemistry and Molecullar Biology. R.H. Burton and P.H. Van Knippenberg (eds). Elsivier-Amsterdam. The Netherlands.

Chinabut, S., C. Limsuwan, and P. Chanratchakool. 1990. Mycobacteriosis in the snake head, Chana striatus (Fowler). J. Fish Dis. 13: 531-535.
Chu Chen, S., A. Adams, K.D. Thomson, and R.H. Randolph. 1997. Development of monoclonal antibodies to the extracellular products of Mycobacterium spp. isolated from Chevron Snakehead and the reference strain Mycobacterium chelonei. J. Aquatic Animal Health 9: 86-98.

DeLuca, D., M. Wilson, and G.W. Warr. 1983. Lymphocyte heterogenecity in the trout, Salmo gairdneri, defined with monoclonal antibodies to IgN. Eur. J. immunol. 13: 546-551.

Harlow, E. and D. Lane. 1988. Antibodies, A laboratory Manual. Cold Spring Harbor Laboratory Press. Cold Spring Harbor, New York.

Kaatari, S., R.Getchell, P. Turaga, and M. Irwin. 1986. Development of Vaccine for Bacterial Kidney Disease in Salmon. U.S. Department of Energi Bonnevile Power Administration Div. of Fish and Wildlife.

Kohler, G. and C. Milstein. 1975. Continous cultures of fused cells secreting antibody of predefined specificity. Nature (London) 256: 495-497.

Lowry, O.H., N.J. Rosebrough, A.L. Farr, and R.J. Randal. 1951. Protein measurement with the folin phenol reagent. J. Biol. Chem. 193, 265.

Limsuwan, C., S. Chinabut, K. Pawapuitanon, and $\mathrm{O}$. Lauhavinit. 1983. Tuberculosis (mycobacteriosis) in snake head (Opiocephalus striatus). N.I.F.I. Tech. paper. Fisheries Department, Thailand.

Lobb, C.J. and L.W. Clem. 1982. Fish lymphocytes differ in the expression of surface immunoglobulin. Dev. Comp. Immunol. 6:473-479.

Nigrelli, R.F. and H. Vogel. 1963. Spontaneous tuberculosis in fish and other cold-blood vertebrates with special reference to Mycobacterium fortuitum Cruz from fish and human lesion. Zoologica 48, 131-144.

Schots, A., R. Pomp, and W.B. Van Muiswinkel. 1992. Production of monoclonal antibodies. In Fish Immu- 
nology. J.S. Stolen, T.C. Fletcher, D.P. Anderson, S.L. Kaatari, and A.F. Rowley (eds.). SOS Publications, 43 DeNormandie Ave., Fair Haven, NJ, USA.

Secombes, C.J., J.J.M. Van Groningen, and E. Egberts. 1983. Separation of lymphocyte subpopulations in carp, Cyprinus carpio, by monoclonal antibodies: immunohis-tochemichal studies. Immunology 48:165-175.

Supriyadi, H. dan P. Taufik. 1981. Identifikasi dan cara penanggulangan penyakit bakterial pada ikan lele (Clarias batrachus). Bull. Perik. I (3):447-454.

Supriyadi, H. dan A. Rukyani. 1990. Immunopropilaksis dengan cara vaksinasi pada usaha budi daya ikan. Seminar Nasional II, Penyakit Ikan dan Udang, Bogor. 16-18 Januari 1990.
Supriyadi, H., Taukhid, dan G. Moekti. 1997. Upaya produksi dan karakterisasi hybridoma untuk penanggulangan bakteri penyakit pada ikan: I. Pembentukan hibridoma penghasil antibodi monoklonal anti Aeromonas hydrophila. J. Bioteknology Pertanian. Vol. 2 No. 1 p. 9-13.

Taufik, P. 1992. Penyakit pada ikan gurami (Osphronemus gouramy Lac.) dan penanggulangannya. Pertemuan Aplikasi Teknologi Budidaya Ikan Gurami, 24-26 Agustus 1992 Yogyakarta.

Thorns, C. and J. Morris. 1983. Production of Monoclonal Antibodies. Bacteriology Department. James Cook University of North Queensland, Townsville, Australia. 